\title{
EL TEATRO ESPAÑOL EN LJUBLJANA ENTRE 1945-1990
}

Una mañana pasada en el archivo del Teatro Nacional de Ljubljana resulta más que suficiente para poder constatar que las obras teatrales españolas han sido estrenadas raramente durante los últimos cuarenta años y esto con mucha irregularidad. Los años cincuenta (el período después de la Segunda Guerra Mundial) se mostraron favorables al teatro español; el público de Ljubljana encuentra en las piezas de Lorca y en las del Siglo de Oro algo diferente. Los espectadores viven el destino trágico, la espera vana, el camino irrealizado, la muerte con la que concluye el anhelo de vivir de los héroes de Lorca; los autores del Siglo de Oro con sus temas caballerescos de honor y de venganza y con su sentido del humor sorprenden y entusiasman. De este modo, se estrenan desde 1949 hasta 1959 tres obras maestras de Lorca: 1950 La casa de Bernarda Alba, 1955 Bodas de sangre y finalmente en 1959 Yerma. Junto con Lorca los señores Molka y Stupica, directores que dominan la escena de entonces, rinden homenaje al Siglo de Oro montando La dama duende de Calderón en 1949, dos años más tarde Fuenteovejuna de Vega y en 1954 Don Gil en las calzas verdes de Tirso de Molina. Algunos estrenos alcanzan un éxito extraordinario. A destacar ante todo La dama duende con 52 representaciones, nada menos.

Sin embargo, en los años sesenta los españoles desaparecen por completo del Teatro Nacional. Otros teatros se encargan de estrenar cada tanto una pieza española, sea Cervantes, cuyos Cuatro entremeses fueron muy populares sobre todo entre los estudiantes, sea Lorca con La zapatera prodigiosa montada por primera vez en Ljubljana en el Teatro de la Juventud.

A principios de los años setenta el teatro español vuelve al Teatro Nacional. Se descubren nuevos autores del siglo XX: Jacinto Benavente con sus Intereses creados en 1971 y Ramón del Valle-Inclán cuyas Divinas palabras se estrenan en 1973, lo que no significa la ausencia completa de la España caballeresca. Al contrario, ya en 1972 El alcalde de Zalamea con la música de Anton Srebotnjak se estrenó en mayo y hasta el fin de la temporada hubo i28 representaciones! - Calderón triunfa después de veintitrés años.

Sigue una cierta calma que dura hasta 1978. Un año raro puesto que en una temporada pudimos ver un Cervantes (Cuatro entremeses, continúan atrayendo al público) y de nuevo un Lorca desconocido, esta vez en el Teatro Municipal. Doña Rosita fue representada cuarenta y seis veces. El lenguaje definitivamente poético de Lorca brilla en un teatro donde se estrenan pocas obras españolas. Desde entonces, desgraciadamente, no podemos hablar de un período particularmente español. 
Durante los últimos diez años, hay sólo dos estrenos a destacar: Mariana Pineda, romance popular en tres estampas, inspirado en la granadina ajusticiada por haber bordado una bandera liberal, en 1831, obra montada en el Teatro Experimental y $L a$ discreta enamorada de Lope, un vaudeville a la manera del siglo XVI, en el Teatro Municipal hace dos años.

El público de Ljubljana sigue sin conocer algunas obras maestras del teatro español. ¿Cómo se podría explicar el hecho de que todavía no se han estrenado en Ljubljana ni La vida es sueño ni El burlador de Sevilla? El teatro romántico se deja entrever gracias a unas operas inmortales de Verdi. ¿Son tan malas nuestras traducciones que no nos atrevemos presentarlas al público? ¿La lengua ha cambiado tanto que resulta indispensable hacer correcciones aunque la traducción sea buena? ¿Los autores ingleses, franceses, escandinavos y norteamericanos son rivales demasiado fuertes y a priori excluyen a los españoles de la competición? El teatro español conoció sin duda tiempos más felices. Lo único que podemos esperary desear los hispanistas eslovenos es que aquellos tiempos vuelvan de nuevo. 